\title{
Stabilization and solidification of electric arc furnace dust originating from steel industry by using low grade MgO
}

\author{
Ahmet Can Bayraktar ${ }^{1}$, Edip Avşar ${ }^{2 *}$, İsmail Toröz ${ }^{1}$, Kadir Alp $^{1}$, Asude Hanedar $^{3}$ \\ ${ }^{1}$ Istanbul Technical University, Turkey \\ Civil Faculty \\ Department of Environmental Engineering \\ ${ }^{2}$ Bitlis Eren University, Turkey \\ Engineering and Architecture Faculty \\ Department of Environmental Engineering \\ ${ }^{3}$ Namık Kemal University, Turkey \\ Corlu Engineering Faculty \\ Department of Environmental Engineering
}

*Corresponding author's e-mail: edipavsar@hotmail.com

Keywords: stabilization, solidification, electric arc furnace dust, TCLP, LG MgO.

\begin{abstract}
In this study, solidification/stabilization (S/S) of electric arc furnace dust (EAFD) which is generated during the production of steel from scrap metals and classified as hazardous waste were investigated by using different ratios of cement and low grade $\mathrm{MgO}(\mathrm{LG} \mathrm{MgO})$ as binding agents. Type I PC $42.5 \mathrm{R}$ portland cement and $\mathrm{LG} \mathrm{MgO}$ which contains $70-80 \% \mathrm{MgO}$ were used. S/S blocks that contain different ratios of binding agents which have 1/0.5 - 1/1 - 1/2 -1/3-1/4 - 1/5 cement/LG MgO ratio and S/S blocks which contain only cement and no LG MgO agents were prepared. These blocks, which contain 3 different waste ratios according to weight, $20 \%, 30 \%$ and $40 \%$ respectively, were produced and exposed to 28 -day water purification. At the end of the purification process, S/S blocks were extracted using TCLP (Toxicity Characteristic Leaching Procedure) tests in order to determine the leaching behavior of $\mathrm{Zn}, \mathrm{Pb}$, and $\mathrm{Cd}$ in $\mathrm{S} / \mathrm{S}$ blocks. By the end of this study, it was concluded that the recovery of EAFD is possible and applicable by immobilization. The findings of the study concluded that environmental performances or structural properties of blocks contain 30\% waste by weight are suitable. This method is a proper one for recovering and treatment of EAFD with mixture of cement and LG MgO.
\end{abstract}

\section{Introduction}

In the last two decades problems related to disposal of hazardous wastes, which are produced in vast amounts by millions of industrial activities around the world, have failed to be solved completely. With recent developments in the world, industrial hazardous wastes gain increasing importance in terms of recycling potential and recovery applications, and thus various technologies have been implemented in an attempt to prevent waste production at its source.

One of the recovery and treatment applications of hazardous wastes is the solidification/stabilization $(\mathrm{S} / \mathrm{S})$ technique which has become prominent as a remediation technology that limits mobility of contaminants in solid, liquid and sludge waste and reduces its leaching potential into the environment (EPA 1986). The S/S technology is an ultimate disposal method and it is also used as a pre-treatment method with the aim of meeting landfill limit values for unacceptable hazardous wastes which have higher concentrations of contaminants. Using this method, the recovery of solid mass is possible by mixing various binding agents, such as cement, with hazardous wastes such as construction materials.

Electric arc furnace dust during steel production is classified as a potential hazardous waste according to the Turkish Hazardous Waste Control Directive because of its high heavy metal concentration (Bayraktar 2011). Application of the $\mathrm{S} / \mathrm{S}$ method is practiced for the purpose of preventing leaching of highly toxic heavy metals into the environment, especially $\mathrm{Zn}, \mathrm{Pb}$, and $\mathrm{Cd}$, which are formed in EAFD. Stabilized wastes are considered acceptable for land disposal from the moment they pass TCLP standards. However, the treatment effectiveness may change later because of environmental conditions and slow physiochemical reactions during aging (Fuessle and Tylor 2004).

Considering characterization studies that have been made for EAFD, heavy metal contents show fluctuations from plant to plant. In spite of variations in the character of EAFD, some intervals were determined by weight for potential elements that are formed in it. Orhan 2005 determined these intervals by weight to be $7-40 \% \mathrm{Zn}, \mathrm{Pb}(4-9 \%)$, Fe (24-27\%), $\mathrm{Cd}(0.1-0.3 \%), \mathrm{Mn}(1-1.5 \%), \mathrm{Si}(1-1.5 \%), \mathrm{Cu}(0.1-0.5 \%)$, $\mathrm{Cr}(0.15-0.25 \%) \mathrm{Cl}(2-4 \%), \mathrm{F}(0.2-0.9 \%)$ (Orhan 2005). 
Total steel production for Turkey was around 29.143 million tons in 2010 (World Steel Association 2011). $72 \%$ of this production is made with an electric arc furnace from scrap metals (State Planning Organization 2007). According to the literature, the amount of EAFD released from steel production changes between 5-30 kg per ton of steel produced (Multilateral Investment Guarantee Agency Environmental Guidelines for Mini Stell Mills 2015). If one accepts the average arc furnace dust released from steel production plants to be around $15 \mathrm{~kg}$ per ton of steel manufactured, according to IPPC BREF Document (Europen Comission 2001), then it can be clearly seen that it is necessary to develop solutions to reduce the amount of waste.

Heavy metals leaching from $\mathrm{S} / \mathrm{S}$ products strongly depends on the $\mathrm{pH}$; thus, the final $\mathrm{pH}$ value of the leachate is the most important variable in terms of ensuring the heavy metal leaching limits (Pereira et al. 2007, Salihoğlu 2007). The final $\mathrm{pH}$ value of the leachate must be within a range of values corresponding to the minimum solubility of the metals in the leaching medium. This is normally achieved in the $\mathrm{pH}$ range of 8.0-11.3 for TCLP leachates (Mitrakas 2007).

Accordingly, in this study the aim was to determine short-term environmental performance of the $\mathrm{S} / \mathrm{S}$ products, including EAFD via stabilization/solidification methods. In this scope the TCLP (Tocixity Characteristic Leaching Procedure) test was used for determination of the heavy metal levels in leaching liquids (EPA, 1992). Additionally, the usage of $\mathrm{LG} \mathrm{MgO}$ was planned as an alternative binding agent to cement.

According to literature it is stated that cement and lime mixture is the most effective binding system in terms of $\mathrm{S} / \mathrm{S}$ of EAFD. But the single application of lime with the aim of $\mathrm{S} / \mathrm{S}$ of the EAFD is problematic because lime increases the systems $\mathrm{pH}$ and this causes the re-solubilitization of $\mathrm{Pb}$ which is an important pollutant in the content of EAFD. On the other hand, $\mathrm{MgO}$ buffers the system $\mathrm{pH}$ between 9-10 interval which provides the minimum solubility for heavy metals (Salihoğlu 2007, Fernandez et al. 2003). But according to literature survey it can be seen that there are very limited works for the usage of $\mathrm{LG} \mathrm{MgO}$ in terms of $\mathrm{S} / \mathrm{S}$ and the aim of this work is to improve this case. The final target of the study was to determine the optimum waste:cement: $\mathrm{LG} \mathrm{MgO}$ ratio in terms of technological applicability. At the same time reuse of LG $\mathrm{MgO}$ is one of the examples of win-win strategy because it is one of the by products derived from the calcination of the meerschaum.

\section{Materials and methods}

In the scope of this study, the $\mathrm{S} / \mathrm{S}$ method was utilized for EAFD by using different ratios of binder which are Type I PC 42.5 R portland cement and $\mathrm{LG} \mathrm{MgO}$ which contains $70-80 \%$ $\mathrm{MgO}$. At the same time, in order to determine the effect of the waste portion in blocks, the amounts of waste were changed in blocks at $20 \%, 30 \%$ and $40 \%$ by weight. Laboratory studies were conducted in four phase that are shown below.

1. Characterization of EAFD

2. Determination of binding agents

3. Application of $\mathrm{S} / \mathrm{S}$ method

4. Determination of environmental properties of $\mathrm{S} / \mathrm{S}$ products

\section{Results and discussion}

\section{Characteristics of electric arc furnace dust}

EAFD was taken from a steel production plant and homogenized for use in laboratory studies. Then dust samples were grinded to a particle diameter of less than $1.2 \mathrm{~mm}$ to use for the $\mathrm{S} / \mathrm{S}$ block production. Some of the EAFD was crushed to a particle diameter of less than $0.25 \mathrm{~mm}$, and tested with XRF (X-Ray Fluorescence) analysis via the Rigaku ZSX Primus II device for the purpose of determining its chemical composition. The results of the analysis are summarized in Table 1.

Heavy metals that leached into the extraction liquid were measured according to the EPA Test Method 1311 via the UNICAM 929 type Atomic absorpsion spectrophotometry, using Horiba-Jobin Yvon Yj 138-Ultrace ICP (Inductively Coupled Plasma) device. The aim was to assess the initial leaching level of heavy metals included in the EAFD sample. The Initial leaching levels of heavy metals and their limit values which play a crucial role in evaluating the hazardous characteristics of waste are given in Table 2.

Table 1. Chemical composition of EAFD

\begin{tabular}{|c|c|c|c|}
\hline \multicolumn{5}{|c|}{ Chemical Composition of EAFD } \\
\hline Elements & \% Weight & Elements & \% Weight \\
\hline $\mathrm{Fe}$ & 36.51 & $\mathrm{Cr}$ & 0.37 \\
\hline $\mathrm{Zn}$ & 35.95 & $\mathrm{P}$ & 0.18 \\
\hline $\mathrm{Ca}$ & 6.19 & $\mathrm{Br}$ & 0.17 \\
\hline $\mathrm{Pb}$ & 5.08 & $\mathrm{Ba}$ & 0.15 \\
\hline $\mathrm{Cl}$ & 4.73 & $\mathrm{Bi}$ & 0.15 \\
\hline $\mathrm{Si}$ & 2.68 & $\mathrm{Ti}$ & 0.11 \\
\hline $\mathrm{K}$ & 2.40 & $\mathrm{Sn}$ & 0.11 \\
\hline $\mathrm{Mn}$ & 2.21 & $\mathrm{Sb}$ & 0.08 \\
\hline $\mathrm{S}$ & 1.17 & $\mathrm{Ni}$ & 0.03 \\
\hline $\mathrm{Mg}$ & 0.68 & $\mathrm{Rb}$ & 0.02 \\
\hline $\mathrm{Al}$ & 0.60 & $\mathrm{Sr}$ & 0.02 \\
\hline $\mathrm{Cu}$ & 0.42 & & \\
\hline
\end{tabular}




\section{Determination of binding agents}

Proper treatment alternatives for disposal of EAFD with the $\mathrm{S} / \mathrm{S}$ method were investigated with regard to different binding materials to be used with Type I $42.5 \mathrm{R}$ cement and with LG $\mathrm{MgO}$ (including $\approx 70 \% \mathrm{MgO}$ ) which stood out as a new binding agent in recent years.

Binding agents and waste ratios used in the $\mathrm{S} / \mathrm{S}$ technology were decided via literature research (Bayraktar 2011). In accordance with the literature data, the $\mathrm{S} / \mathrm{S}$ blocks possessing various ratios of cement/LG $\mathrm{MgO}$ between $1 / 0.5-1 / 5$, were planned to be produced. These blocks, which contain 3 different ratios of waste according to weight, $20 \%$, $30 \%$ and $40 \%$ respectively, were produced and exposed to a 28-day water purification. The amounts of the components of $\mathrm{S} / \mathrm{S}$ blocks produced are given in Table 3 .

\section{Application of S/S method}

EAFD, cement and $\mathrm{LG} \mathrm{MgO}$ were mixed properly according to the amounts of each compound shown in Table III. The mixing procedures were initially performed slowly (around self axes $140 \pm 5 \mathrm{rpm}$, around vessel $62 \pm 5 \mathrm{rpm}$ ) and then at a faster rate (around self axes $285 \pm 10 \mathrm{rpm} / \mathrm{min}$., around vessel $125 \pm 10 \mathrm{rpm} / \mathrm{min}$.) for approximately 4 minutes. Afterwards, mortars obtained were poured into a mold with dimensions of $4 \times 4 \times 16 \mathrm{~cm}$. All paste samples were prepared according to TS EN 12390-2.

Table 2. Initial leaching concentration of unprocessed EAFD and limit values of related regulations

\begin{tabular}{|l|c|c|c|}
\hline \multicolumn{1}{|c|}{ Contaminats } & $\begin{array}{c}\text { Leaching Results } \\
\text { of Unprocessed EAFD } \\
(\mathrm{mg} / \mathrm{L})\end{array}$ & $\begin{array}{c}\text { EPA TCLP Test } \\
\text { Limit Values } \\
(\mathrm{mg} / \mathrm{L})(\text { EPA 1992) }\end{array}$ & $\begin{array}{c}\text { EPA Land Disposal } \\
\text { Restriction Limit Values } \\
(\mathrm{mg} / \mathrm{L})(\text { EPA 1994) }\end{array}$ \\
\hline Nickel $(\mathrm{Ni})$ & $<0.25$ & - & 11.0 \\
\hline Manganese $(\mathrm{Mn})$ & 10.84 & - & - \\
\hline Iron $(\mathrm{Fe})$ & $<0.25$ & 5.0 & - \\
\hline Lead(Pb) & 14.9 & - & 0.75 \\
\hline Zinc $(\mathrm{Zn})$ & 1539 & - & 4.3 \\
\hline Copper(Cu) & 0.97 & 1.0 & - \\
\hline Cadmium $(\mathrm{Cd})$ & 17.64 & 5.0 & 0.11 \\
\hline Chromium $(\mathrm{Cr})$ & $<0.25$ & & 0.6 \\
\hline
\end{tabular}

Table 3. Amount of component of S/S blocks produced

\begin{tabular}{|c|c|c|c|c|c|c|c|}
\hline \multicolumn{3}{|c|}{ Ratios } & \multicolumn{4}{|c|}{ Mass (gram) } & \multirow{2}{*}{ Water/Solid Ratios } \\
\hline EAFD & Cement & LG MgO & Waste & Cement & LG MgO & Water & \\
\hline $20 \%$ & 1 & 0.5 & 375 & 1000 & 500 & 450 & 0.24 \\
\hline $20 \%$ & 1 & 1 & 375 & 750 & 750 & 480 & 0.26 \\
\hline $20 \%$ & 1 & 2 & 375 & 500 & 1000 & 544 & 0.29 \\
\hline $20 \%$ & 1 & 3 & 375 & 375 & 1125 & 550 & 0.30 \\
\hline $20 \%$ & 1 & 4 & 375 & 300 & 1200 & 590 & 0.32 \\
\hline $20 \%$ & 1 & 5 & 375 & 250 & 1250 & 580 & 0.31 \\
\hline $20 \%$ & $80 \%$ & - & 375 & 1500 & - & 425 & 0.23 \\
\hline $30 \%$ & 1 & 0.5 & 570 & 886.7 & 443.3 & 380.6 & 0.200 \\
\hline $30 \%$ & 1 & 1 & 570 & 665 & 665 & 382.0 & 0.201 \\
\hline $30 \%$ & 1 & 2 & 570 & 443.3 & 886.7 & 406.3 & 0.213 \\
\hline $30 \%$ & 1 & 3 & 570 & 332.5 & 997.5 & 410.8 & 0.216 \\
\hline $30 \%$ & 1 & 4 & 570 & 266 & 1064 & 423.3 & 0.222 \\
\hline $30 \%$ & 1 & 5 & 570 & 221.7 & 1108.3 & 426.0 & 0.224 \\
\hline $30 \%$ & $70 \%$ & - & 570 & 1330 & - & 396.0 & 0.208 \\
\hline $40 \%$ & 1 & 0.5 & 700 & 700 & 350 & 325.2 & 0.185 \\
\hline $40 \%$ & 1 & 1 & 700 & 525 & 525 & 341.8 & 0.195 \\
\hline $40 \%$ & 1 & 2 & 700 & 350 & 700 & 346.1 & 0.198 \\
\hline $40 \%$ & 1 & 3 & 700 & 262.5 & 787.5 & 351.2 & 0.200 \\
\hline $40 \%$ & 1 & 4 & 700 & 210 & 840 & 356.4 & 0.203 \\
\hline $40 \%$ & 1 & 5 & 700 & 175 & 875 & 356.5 & 0.203 \\
\hline $40 \%$ & $60 \%$ & - & 700 & 1050 & - & 338 & 0.193 \\
\hline
\end{tabular}




\section{Determination of environmental properties of $\mathrm{S} / \mathrm{S}$ products}

After samples were taken from the molds, they were put into a container filled with water and held there for purification for 28 days. At the end of this period, the samples were crushed to a particle diameter of less than $9.5 \mathrm{~mm}$. After that, TCLP tests were completed in order to measure the concentration of heavy metal leached by the extraction.
The TCLP test procedure shows the maximum amount of leachable heavy metal in order to simulate the worst-case scenario for environmental conditions. Hence it is possible to use its data reliably in the stage of determining the capacity of the recovery method. $\mathrm{Zn}, \mathrm{Pb}$ and $\mathrm{Cd}$ concentrations in the extraction liquid after the $\mathrm{S} / \mathrm{S}$ technique are given respectively in Figures 1, 2 and 3.

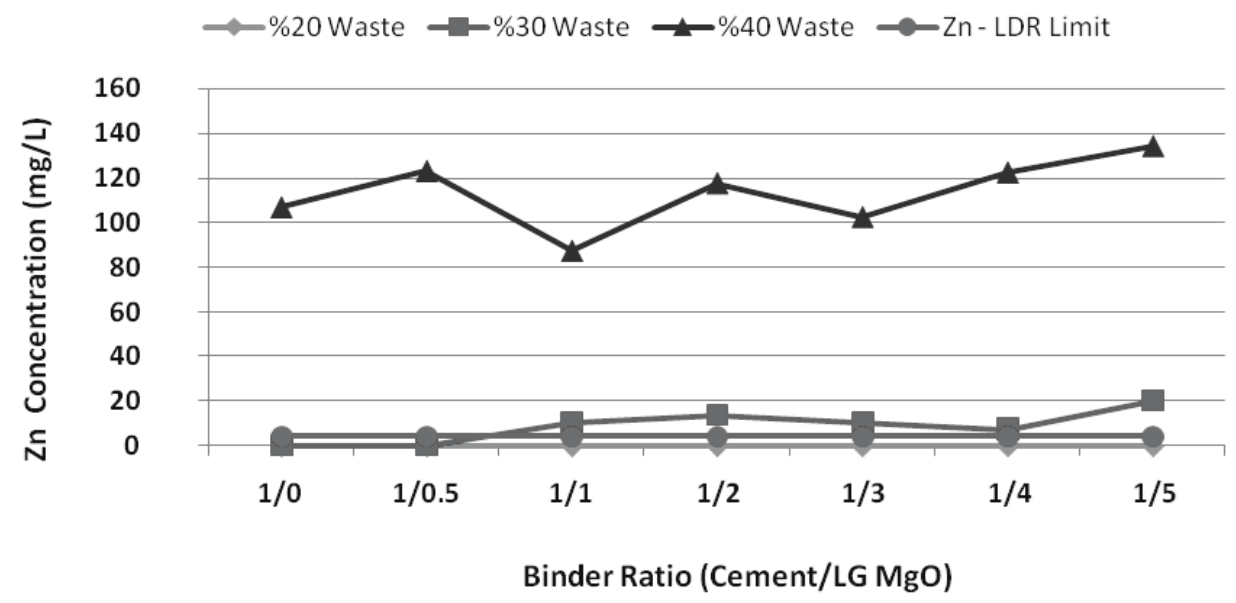

Fig. 1. Comparison of leaching levels of $\mathrm{Zn}$ for different waste ratios and landfilling limit

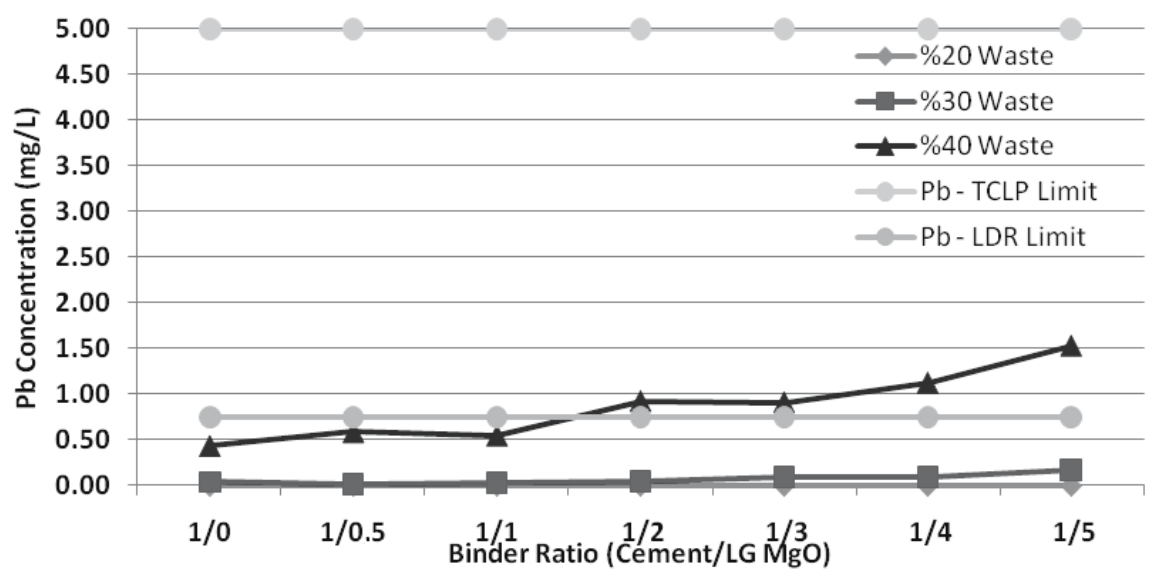

Fig. 2. Comparison of leaching levels of $\mathrm{Pb}$ for different waste ratios and landfilling limit

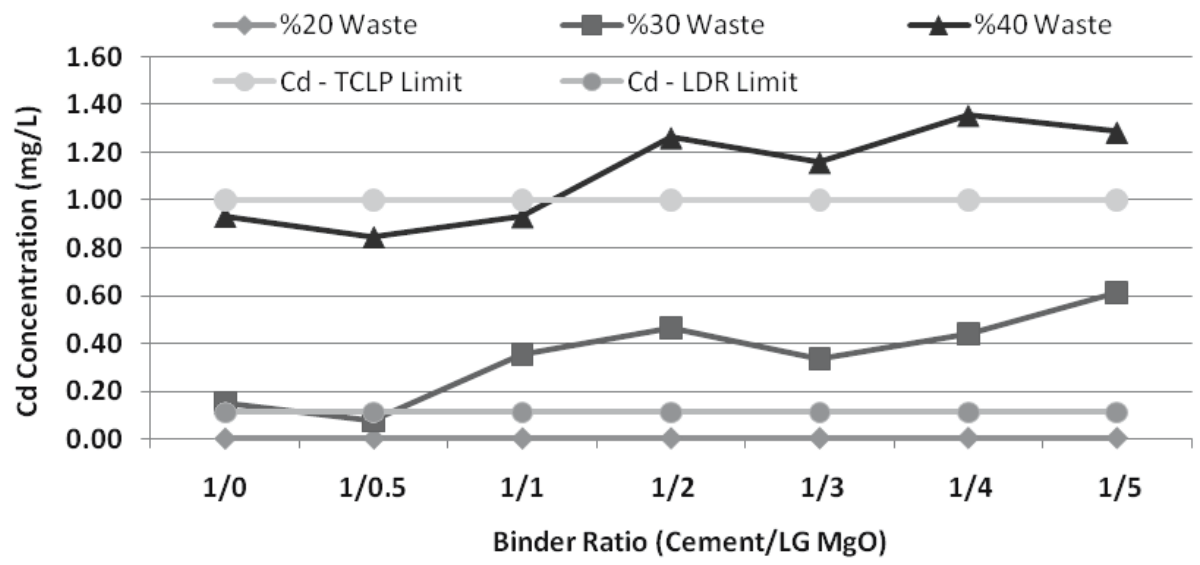

Fig. 3. Comparison of leaching levels of $\mathrm{Cd}$ for different waste ratios and landfilling limit 


\section{Conclusions}

On the basis of the literature review and the experimental studies, the $\mathrm{S} / \mathrm{S}$ technology was demonstrated to be a proper disposal/treatment method before landfilling. The $\mathrm{S} / \mathrm{S}$ systems which have a high $\mathrm{pH}$ level were those which consisted of cement and LG MgO together. Toxic metals, in this case $\mathrm{Zn}$, $\mathrm{Pb}$, and $\mathrm{Cd}$, formed in the waste have been shown to be fixed by converting metal forms that have low solubility. In systems with a higher $\mathrm{pH}$, the resolution of $\mathrm{Pb}$ was precluded through the usage of LG MgO due to interference. Although LG $\mathrm{MgO}$ has a higher buffer capacity against acidic solutions, in this case, it appeared not to work well enough in terms of decreasing the leaching of heavy metals. The results showed that the leaching values of $\mathrm{Zn}, \mathrm{Pb}$ and $\mathrm{Cd}$ increased upon raising the amount of $\mathrm{LG} \mathrm{MgO}$ in the $\mathrm{S} / \mathrm{S}$ blocks.

If the Figures above are regarded as accurate, some results can be obtained as listed below:

- Although the leaching value of $\mathrm{Zn}$ is considerably low for a waste ratio of $20 \%$ as shown in Figure 3, the $\mathrm{S} / \mathrm{S}$ blocks including waste ratios of $30 \%$ and $40 \%$ are shown to have inadequate treatment efficiency.

- Although LG MgO has a buffering effect on the $\mathrm{pH}$ of the system, increasing the amount of $\mathrm{LG} \mathrm{MgO}$ made $\mathrm{Pb}$ more leachable. On the other hand, $\mathrm{Pb}$ does not exceed the TCLP limit value of $5 \mathrm{mg} / \mathrm{L}$ for any waste ratio.

- Despite the removal of hazardous characteristics of EAFD caused by $\mathrm{Cd}$, it is extremely hard to meet EPA land disposal acceptance criteria of $0.11 \mathrm{mg} / \mathrm{L}$.

- Treatment of $\mathrm{Zn}, \mathrm{Pb}$ and $\mathrm{Cd}$ with the $\mathrm{S} / \mathrm{S}$ process is hardly dependant on $\mathrm{pH}$ and it was observed that increasing the levels of $\mathrm{LG} \mathrm{MgO}$ increases the leaching potential of heavy metals.

- High concentrations of heavy metals in the components of EAFD (about 42\%) do not let it be used as a concrete additive material for large amounts of waste. Because it was determined that hydration reactions are limited, postponed or prevented by increasing $\mathrm{Zn}, \mathrm{Pb}$ and $\mathrm{Cd}$ heavy metal concentrations thus this case affects $\mathrm{S} / \mathrm{S}$ products pressure and tensile strength negatively.

- Optimum treatment performance is obtained with binding ratios of $1 / 0.5$ and an EAFD ratio of $30 \%$ by weight. Adequate treatment formula was determined as $30 \%$ Waste $+46.6 \%$ Cement $+23.3 \%$ LG $\mathrm{MgO}$. Blocks produced according to this formula provided pressure strength approximately $6 \mathrm{MPa}$, it is closer to cements strength $(7-8 \mathrm{MPa})$ and it is suitable in terms of landfilling or using as a lean concrete. Block's tensile strength was determined approximately $3 \mathrm{MPa}$, which means it can be used as unskilled building material (like cobblestone).

\section{References}

Bayraktar, C. (2011). Solidification and stabilization of electric arc furnace dust originated from steel production by using low grade $\mathrm{MgO}$ additive, Master Thesis ITU Graduate School of Institute of Science Engineering and Technology, Turkey. (in Turkish)

EPA (1986). Handbook for stabilization/solidification of hazardous wastes, (http://nepis.epa.gov/Adobe/PDF/10001GY8.PDF/ (01.06.2015))

EPA (1992). EPA Test Method 1311, Toxicity characteristic leaching procedure, (http://www.epa.gov/osw/hazard/testmethods/ sw846/pdfs/1311.pdf/(01.06.2015))

EPA (1994). Land disposal restrictions phase II universal treatment standards, (http://www.epa.gov/epawaste/laws-regs/state/ revision/frs/fr137-1.pdf/(01.06.2015))

European Commission (2001). IPPC Reference Document on Best Available Techniques for the Production of Iron and Steel, (http://eippcb.jrc.ec.europa.eu/reference/BREF/IS Adopted_03_2012.pdf/(01.06.2015))

Fernandez, A.I., Chimenos, J.M., Raventos, N., Miralles, L. \& Espiell, F. (2003). Stabilization of electrical arc furnace dust with low-grade $\mathrm{MgO}$ prior to landfill, Journal of Environmental Engineering, 129, 3, pp. 275-279.

Fuessle, R.W. \& Tylor, M.A. (2004). Long term solidification/ stabilization and toxicity characteristic leaching procedure for electric arc furnace dust, Journal of Environmental Engineering, 130, 5, pp. 492-498.

Mitrakas, M.G., Sikalidis, C.A. \& Karamanl,, T.P. (2007). Immobilization of EAFD heavy metals using acidic materials, Journal of Environmental Science and Health, Part A, 42, pp. 535-541.

Multilateral Investment Guarantee Agency Environmental Guidelines for Mini Stell Mills (2015), (http://www.miga.org/ documents/MiniSteelMills.pdf/(01.06.2015))

Orhan, G. (2005). Leaching and cementation of heavy metals from electric arc furnace dust in alkaline medium, Hydrometallugy, 78, pp. 236-245.

Pereira, C.F., Galiano, Y.L., Rodriguez-Rinero, M.A. \& Parapar, J.V. (2007). Long and short-term performance of a stabilized/ solidified electric arc furnace dust, Journal of Hazardous Materials, 148, pp. 701-707.

Salihoğlu, G. (2007). Solidification and stabilization of heavy metal included steel manufacturing industry wastes, PhD Thesis, Uludağ University, Institute of Science and Technology, Turkey. (in Turkish)

State Planning Organization (2007). The ninth five-year development plan, main metal industry, special commission report on iron and steel industry, (http://www.kalkinma.gov.tr/Lists/ zel\%20htisas\%20Komisyonu\%20Raporlar/Attachments/3/ oik667.pdf/(01.06.2015)). (in Turkish)

World Steel Association, (2011). Steel Statistic Year Book 2011, World Steel Committee on Economic Studies, (http:// www.worldsteel.org/dms/internetDocumentList/statisticsarchive/yearbook-archive/Steel-statistical-yearbook-2011/ document/Steel\%20statistical\%20yearbook\%202011. pdf/01.06.2015)) 